\title{
Oceanographic conditions structure forage fishes into lipid-rich and lipid-poor communities in lower Cook Inlet, Alaska, USA
}

\author{
Alisa A. Abookire ${ }^{1,2, *}$, John F. Piatt ${ }^{1}$ \\ ${ }^{1}$ Alaska Science Center, US Geological Survey, 1011 East Tudor Road, Anchorage, Alaska 99503, USA \\ ${ }^{2}$ Present address: Alaska Fisheries Science Center, National Marine Fisheries Service, Kodiak Laboratory, 301 Research Court, \\ Kodiak, Alaska 99615 USA
}

\begin{abstract}
Forage fishes were sampled with a mid-water trawl in lower Cook Inlet, Alaska, USA, from late July to early August 1996 to 1999. We sampled 3 oceanographically distinct areas of lower Cook Inlet: waters adjacent to Chisik Island, in Kachemak Bay, and near the Barren Islands. In 163 tows using a mid-water trawl, 229437 fishes with fork length $<200 \mathrm{~mm}$ were captured. More than 39 species were captured in lower Cook Inlet, but Pacific sand lance Ammodytes hexapterus, juvenile Pacific herring Clupea pallasi, and juvenile walleye pollock Theragra chalcogramma comprised $97.5 \%$ of the total individuals. Both species richness and species diversity were highest in warm, lowsalinity, weakly stratified waters near Chisik Island. Kachemak Bay, which had thermohaline values between those found near Chisik Island and the Barren Islands, had an intermediate value of species richness. Species richness was lowest at the Barren Islands, an exposed region that regularly receives oceanic, upwelled water from the Gulf of Alaska. Non-metric multidimensional scaling (NMDS) was used to compute axes of species composition based on an ordination of pairwise site dissimilarities. Each axis was strongly rank-correlated with unique groups of species and examined separately as a function of environmental parameters (temperature, salinity, depth), area, and year. Oceanographic parameters accounted for 41 and $12 \%$ of the variability among forage fishes indicated by Axis 1 and Axis 2, respectively. Axis 1 also captured the spatial variability in the upwelled area of lower Cook Inlet and essentially contrasted the distribution of species among shallow, nearshore (sand lance, herring) and deep, offshore (walleye pollock) habitats. Axis 2 captured the spatial variability in forage fish communities from the north (Chisik Island) to the south (Barren Islands) of lower Cook Inlet and essentially contrasted a highly diverse community dominated by salmonids and osmerids (warmer, less saline) with a fish community dominated by Pacific sand lance (colder, more saline). Axis 3 reflected the negative spatial association of capelin Mallotus villosus and Pacific cod Gadus macrocephalus. Correlations of year with Axes 1 and 3 indicate that from 1996 to 1999 the forage fish community significantly decreased in lipid-poor gadids (walleye pollock and Pacific cod), and significantly increased in lipid-rich species such as Pacific sand lance, Pacific herring, and capelin.
\end{abstract}

KEY WORDS: Community structure $\cdot$ Forage fish $\cdot$ Lipid $\cdot$ Mid-water distribution $\cdot$ Capelin $\cdot$ Gadids Cook Inlet · Gulf of Alaska

- Resale or republication not permitted without written consent of the publisher

\section{INTRODUCTION}

Forage fish populations ${ }^{1}$ in the Gulf of Alaska fluctuate in abundance over a range of temporal and spatial scales (Bechtol 1997, Anderson \& Piatt 1999, Mueter \&

\footnotetext{
${ }^{1}$ The term 'forage fishes' applies to mid-water, schooling fishes that are prey to marine mammals, seabirds, and larger fishes during some phase of their life-history (Springer \& Speckman 1997)
} 
Norcross 2000). After a climatic regime shift occurred in the North Pacific during the late 1970s (Francis et al. 1998, Hare \& Mantua 2000), gadid and flatfish populations increased dramatically while shrimp and capelin Mallotus villosus populations virtually disappeared (Anderson et al. 1997, Anderson \& Piatt 1999, Mueter $\&$ Norcross 2000). This trophic reorganization is hypothesized to be an important contributor to declines in populations of seabirds (Piatt \& Anderson 1996) and marine mammals (Merrick et al. 1987), because lipidpoor gadids and flatfishes generally replaced lipid-rich fish species in the Gulf of Alaska food web. On a smaller temporal scale, El Niño Southern Oscillation (ENSO) events in the northern Gulf of Alaska may be associated with changes in the distribution and recruitment of pelagic juvenile stages of Pacific herring Clupea pallasi (hereafter referred to as herring) and groundfishes (Mysak 1986, Bailey et al. 1995, Piatt et al. 1999). Understanding the response of fish populations to changes in physical oceanography is an important step toward understanding the effects of climatic shifts on marine piscivores (McGowan et al. 1998, Kitaysky \& Golubova 2000, Stenseth et al. 2002, Chavez et al. 2003).

Forage fishes typically consume zooplankton, at least in their juvenile stage, and serve as a critical ecosystem link as they transfer energy to higher trophic levels. Myctophids (family Myctophidae), Pacific sand lance Ammodytes hexapterus (hereafter referred to as sand lance), and capelin are highly efficient in this energy transfer (Van Pelt et al. 1997, Anthony et al. 2000), and vary in nutritional value with season and age (Payne et al. 1999, Robards et al. 1999a). Because most forage fishes have relatively short life spans, early maturation, and high fecundity, their populations are prone to rapid fluctuations as a result of predation and environmental change (Anderson \& Piatt 1999, Chavez et al. 2003). Such fluctuations in forage fish populations often have direct consequences on the foraging success and survival of piscivores (Kitaysky \& Golubova 2000, Chavez et al. 2003), especially when the reorganization of a forage fish community shifts between lipid-rich and lipid-poor species (Piatt \& Anderson 1996, Anderson \& Piatt 1999).

Previous studies in lower Cook Inlet have examined nearshore ( $<1 \mathrm{~km}$ from shore) fish communities at varying temporal (Robards et al. 1999b) and spatial (Blackburn et al. 1980, Abookire et al. 2000) scales, but little is known about the structure of mid-water forage fish communities on the shelf. Here we investigate 2 questions: (1) does variability in physical oceanography determine the distribution of mid-water fishes; (2) are lipid-rich and lipid-poor fish communities favored by different oceanographic conditions? To answer this, we examined geographic variability in species richness, diversity, and fish community structure, and then related axes of fish species composition to oceanic patterns in lower Cook Inlet. Multivariate axes were used to summarize the major patterns of variation in species composition, identify fish species that account for the observed changes, and examine the observed patterns of change in relation to environmental parameters (temperature, salinity, depth), area and year.

\section{MATERIALS AND METHODS}

Study area. Cook Inlet is a large estuary in the northern Gulf of Alaska (Fig. 1). Water circulation in lower Cook Inlet is counterclockwise, as Gulf of Alaska water enters just east of the Barren Islands, through Kennedy Entrance, and flows out along the west side of Cook Inlet, past Chisik Island, into Shelikof Strait (Royer 1975). Waters around Chisik Island receive input from glacier-fed rivers on the mainland as well as turbid, freshwater input from large rivers at the head of Cook Inlet (Muench et al. 1978). Kachemak Bay is a highly stratified, estuarine environment that receives oceanic, nutrient-rich water from localized upwelling in central lower Cook Inlet (Muench et al. 1978, Abookire et al. 2000). The Barren Islands are exposed and receive oceanic, upwelled water from the Gulf of Alaska (Drew \& Piatt 2002).

Fish collections. Fishes in lower Cook Inlet, Alaska, were sampled from 16 to 25 July 1996, 19 July to 2 August 1997, 21 July to 9 August 1998 and 25 July to 11 August 1999. Sampling was focused on waters within a $45 \mathrm{~km}$ radius of 3 seabird colonies in lower Cook Inlet: Duck and Chisik Islands (Chisik), Gull Island in Kachemak Bay (Kachemak), and the Barren Islands (Barrens, Fig. 1). Nearshore and offshore transect lines were surveyed in each area with a Biosonics DT4000 echosounder, using a $120 \mathrm{kHz}$ transducer and acquisition threshold of $-80 \mathrm{~dB}$. Generally transect lines were similar among years, with the exception of 1996 when sampling effort extended farther west (see Speckman \& Piatt 2002). Trawl stations were selected on the basis of acoustic signal strength. When a significant fish sign was detected on the echosounder, we transited over the entire acoustic layer and then returned to the location where the signal began and sampled with a mid-water trawl through the layer.

A modified mid-water herring trawl with a mouth opening of $50 \mathrm{~m}^{2}$ was fished from a $22 \mathrm{~m}$ stern trawler. Mesh sizes diminished stepwise from $5 \mathrm{~cm}$ in the wings to $1 \mathrm{~cm}$ at the codend, which was lined with $3 \mathrm{~mm}$ mesh. A plastic codend collecting bucket with $1000 \mu \mathrm{m}$ mesh was detached and rinsed after each tow. A Furuno net-sounding system monitored the depth of the net headrope while fishing. The target towing 
speed was 2.5 knots, and all fishing occurred during daylight hours. The average tow duration was $25 \mathrm{~min}$ in 1996, 15 min in 1997, and 10 min in 1998 and 1999. Tow duration was reduced in an attempt to more accurately classify discrete backscatter signals with our catch. Tow start and end locations were recorded with a global positioning system unit when trawl doors were at the water surface. The distance fished was determined whenever possible as the sum distance between latitude and longitude points taken every $1 \mathrm{~min}$ along the tow path. Catch-per-unit-effort (CPUE) was standardized to a distance fished of $1 \mathrm{~km}$, and no allowance was made for net mensuration.

Thermohaline collections. After fishing at a station, a conductivity-temperature-density instrument (CTD, Seabird Electronics, SBE-19 SEACAT profiler) was

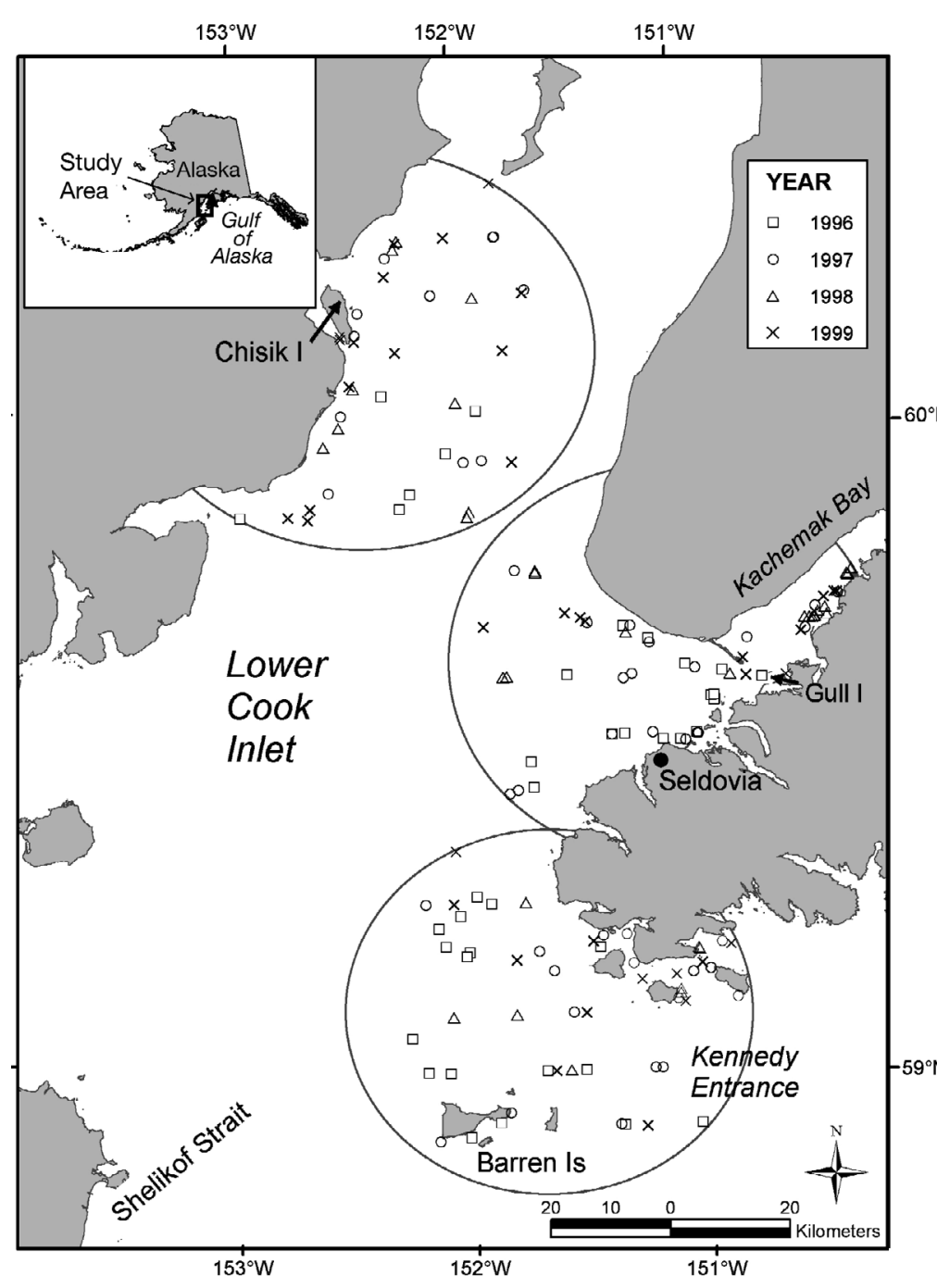

Fig. 1. Stations (163) sampled with a mid-water trawl in lower Cook Inlet, Alaska, from 1996 to 1999. Sampling effort was focused within a $45 \mathrm{~km}$ foraging range of 3 seabird colonies in lower Cook Inlet: Duck and Chisik Islands (Chisik), Gull Island in Kachemak Bay (Kachemak), and Barren Islands (the Barrens). Ellipses enclose stations considered in each area deployed to measure water temperature $\left({ }^{\circ} \mathrm{C}\right)$, salinity (psu), and depth (m). Vertical CTD measurements were obtained at $1 \mathrm{~s}$ intervals and averaged $(\mathrm{n} \approx 3)$ into $1 \mathrm{~m}$ depth bins. Vertical profiles of temperature $(T)$ and salinity $(S)$ were visually analyzed for each tow, and a typical CTD profile from each area was plotted in a $T$-S diagram (Fig. 2). $T-S$ diagrams consider the distribution of temperature and salinity simultaneously and provide a clear visual comparison of the unique water masses in lower Cook Inlet.

Surface $(<10 \mathrm{~m})$ temperatures and salinities were compared among areas with separate 1-way ANOVAs by area. Assumptions for homogeneity of variances and normality were met for the ANOVAs. Bonferroni all-pairwise multiple-comparison tests followed the ANOVAs to test for differences among areas. For each station, thermohaline data were obtained at the average targeted fishing depth (m) of the net headrope and are hereafter referred to as fishing temperature and fishing salinity.

Strong correlations existed between fishing depth and fishing temperature $(\mathrm{r}=$ $0.62)$, fishing depth and fishing salinity $(\mathrm{r}=$ $0.48)$, and fishing salinity and fishing temperature $(r=0.77)$. Because these 3 environmental variables were all highly correlated, there was not enough contrast in the data to separate their effects. Therefore, principal component analysis (PCA) was used to derive the first principal component of environmental (ENV) variables: fishing depth $(\mathrm{m})$, fishing temperature $\left({ }^{\circ} \mathrm{C}\right)$, and fishing salinity (psu). PCA-ENV was used as a proxy for overall variability in temperature, salinity and depth.

Fish measurements. All fishes were identified in the field to the highest taxonomic separation possible and counted; fork length (FL) was measured to the nearest millimeter with an electronic fish-measuring board (Limnoterra). Snake prickleback Lumpenus sagitta were not distinguished from slender eelblenny $L$. fabricii because juveniles are difficult to differentiate without a microscope; hence, they were identified to genus. If $>100$ individuals of the same species were captured in a single tow, a random subsample of 50 to 100 fish was measured. Only fishes of $<200$ mm FL were analyzed, and they constituted the majority $(96.8 \%)$ of all fishes captured. All larval fishes were omitted from analyses, as the net was not designed to effectively capture larval fishes. 
Statistical analyses. For each of the 3 areas sampled, the Shannon-Wiener index of species diversity (Krebs 1989) and species richness (total no. of species caught) were calculated using CPUE data. Non-metric multidimensional scaling (NMDS, Statistical Sciences 1995) was used to summarize patterns in species composition of the forage fish community based on an ordination of pairwise site dissimilarities, following Field et al. (1982) and Mueter \& Norcross (1999, 2000). NMDS was used to construct axes of species composition independently of environmental parameters (see below), thereby minimizing circular ambiguities about relationships between biota and physical parameters (Field et al. 1982).

Frequency of occurrence was used to determine which species to consider in NMDS analyses. Only species (or genera in the case of Lumpenus spp.) present at $\geq 5 \%$ of the stations were evaluated to avoid spurious groups of rare species (Field et al. 1982). In addition, stations with a CPUE of $<5$ fish $\mathrm{km}^{-1}$ were omitted from NMDS analysis. Catch data were transformed by taking the 4 th root of the CPUE (see Field et al. 1982). The dissimilarity in species composition between each pair of sites was computed from rootroot-transformed CPUE data using the Bray-Curtis measure of dissimilarity. The resulting Bray-Curtis site dissimilarity matrix was used as an input for NMDS iterations.

The stress criterion (Kruskal 1964) was used to evaluate goodness-of-fit for the final NMDS model, as it measures how well the pairwise distances in the final NMDS configuration approximate true distances in the Bray-Curtis dissimilarity matrix. The initial NMDS ordination was carried out in 2 dimensions, and the



Fig. 2. Typical water temperature $\left({ }^{\circ} \mathrm{C}\right)$ and salinity (psu) properties of each area. For each area, 1 data point is plotted for each $1 \mathrm{~m}$ of a representative temperature and salinity profile obtained from a single CTD cast. Water column at Chisik was warmest, least saline, and least dense of the 3 areas; at the Barrens, water density was greatest and remained relatively constant from surface to depth, a result of turbulent mixing of entire water column in that area number of dimensions was increased until a Kruskal's stress $<15 \%$ was achieved (Mueter \& Norcross 2000). The orientation of axes derived from NMDS is arbitrary, and therefore the solution was rotated so that the first axis corresponded to the axis of maximum variation (Field et al. 1982).

In the final NMDS configuration, station 'scores', which were assigned from the Bray-Curtis dissimilarity matrix to each station along each axis, were used as indices of species composition (hereafter referred to as axes). Station scores were correlated with fish CPUE along each of the rotated axes using Spearman rankcorrelation to interpret which species were represented by each axis. A species was associated with an axis if it had a rank-correlation of \pm 0.35 or greater (Mueter \& Norcross 2000). Each axis was strongly rank-correlated with unique groups of species and interpreted to represent independent aspects of community composition.

NMDS axes were then related to PCA-ENV using multiple regression. Additionally, station scores along each axis were examined for relation to area (Chisik, Kachemak, Barrens) and year (1996 to 1999) using Kruskal-Wallis rank-sum tests, where the parameter ' $H$ ' is the Kruskal-Wallis test statistic, followed by Kruskal-Wallis multiple $Z$-value comparison tests. Significance for all tests was established at $\mathrm{p}<0.05$.

\section{RESULTS}

Sampling sites ranged in bottom depth from 10 to $197 \mathrm{~m}$, and fishing depth from 5 to $110 \mathrm{~m}$. Most fish $(93 \%)$ were captured at mid-water depths $<40 \mathrm{~m}$. Among the CTD profiles $(n=163)$, fishing temperature and fishing salinity ranged from 7.3 to $12.8^{\circ} \mathrm{C}$ and 27.4 to $32.5 \mathrm{psu}$, respectively. Typically, waters around Chisik were warmest and least saline throughout the water column (Fig. 2). Surface water $(<10 \mathrm{~m})$ temperatures were significantly warmer at Chisik than at Kachemak or the Barrens (ANOVA: $F=26.37, \mathrm{df}=2$, $\mathrm{p}<0.0001$, Fig. 3). Surface water $(<10 \mathrm{~m})$ salinities varied significantly among all areas (ANOVA: $F=$ 40.80, $\mathrm{df}=2, \mathrm{p}<0.0001$ ); salinity values were lowest at Chisik, moderate in Kachemak, and highest at the Barrens (Fig. 3). Kachemak surface temperatures reflected the input of upwelled, oceanic water from the Barrens. Throughout the water column, thermohaline values at the Barrens were the most dense (Fig. 2), representing the oceanic influence from the Gulf of Alaska in that area.

Overall, 229437 fishes were collected in 163 midwater tows during 1996 to 1999 (Table 1). Of the 39 species collected, sand lance, herring, and walleye pollock Theragra chalcogramma (hereafter referred to as 
pollock) comprised $97.5 \%$ of the total individuals (Table 1). Sand lance was the most frequently captured species and was present at $61 \%$ of the stations. The relative abundance of juvenile pollock declined from 1996 to 1999. A 4 th species, capelin, contributed $1.7 \%$ of the total species composition, and catch varied both geographically (Table 1) and interannually (e.g. 76\% of capelin were caught in 1999).

General geographic patterns in species diversity and richness were apparent. Mid-water catches near Chisik were the most diverse (Table 1), and several species comprised $>1 \%$ of the community composition: capelin (23.5\%), longfin smelt Spirinchus thaleichthys $(4.5 \%)$, pollock $(1.9 \%)$, pink salmon Oncorhynchus gorbuscha $(1.7 \%)$, Pacific sandfish Trichodon trichodon (1.6\%), Lumpenus spp. (1.5\%), and chinook salmon Oncorhynchus tshawytscha (1.3\%). Chisik had the highest species richness among areas (32 species), twice the number found at the Barrens (Table 1). Midwater catches at the Barrens and Kachemak were usually single-species (sand lance) schools or a mixture of sand lance with either pollock (Kachemak) or herring (Barrens).

\section{NMDS results}

The final NMDS ordination of species abundance considered 141 stations and had 3 dimensions, with a stress value of $12 \%$. Each of the 3 axes represents a distinct group of fishes. Axis 1 accounted for $49.7 \%$ of the overall variation in fish community composition and had strong positive rank-correlations with CPUE of sand lance and herring and a strong negative rankcorrelation with pollock (Table 2). Axis 2 accounted for $27.1 \%$ of the overall variation in fish community composition. Sand lance was the only species positively correlated with Axis 2, while 6 species negatively correlated with Axis 2, thus contrasting sand lance with chinook salmon, Pacific sandfish, longfin smelt, pink salmon, Lumpenus spp. and Pacific cod Gadus macrocephalus. Axis 3 accounted for the least variation $(23.2 \%)$ in fish community composition and had a strong positive rank-correlation with capelin and a strong negative rank-correlation with Pacific cod. Sockeye salmon Oncorhynchus nerka and prowfish Zaprora silenus did not correspond with any of the 3 axes (Table 2); thus, the variability in their distribution was not captured by the final NMDS configuration.

\section{NMDS variation in relation to physical parameters}

The PCA-ENV variable explained $75.2 \%$ of the variation in fishing temperature $\left({ }^{\circ} \mathrm{C}\right)$, salinity (psu), and
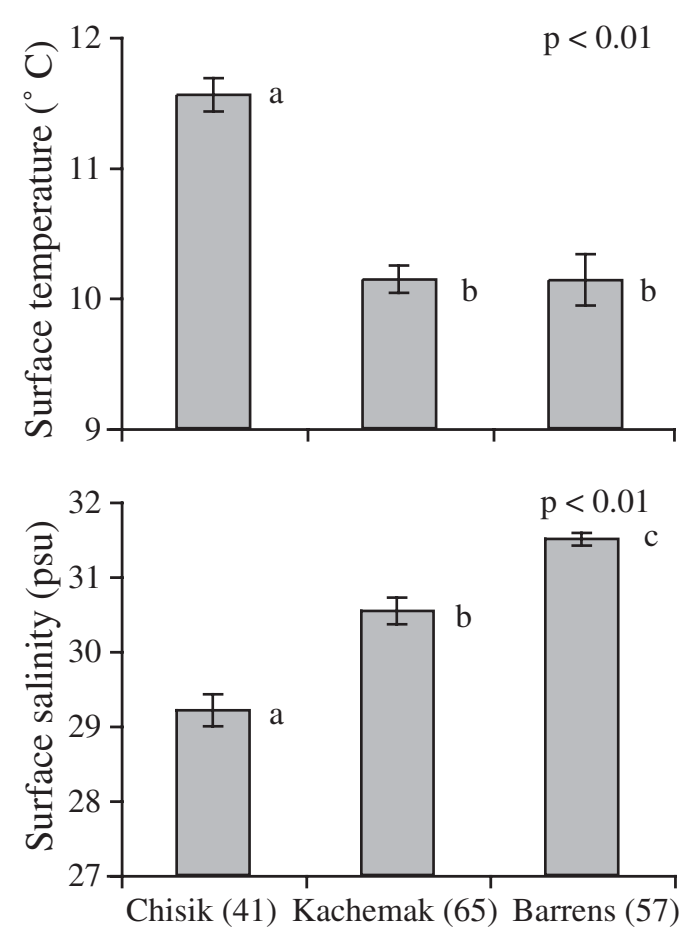

Fig. 3. Mean $( \pm \mathrm{SE})$ surface $(<10 \mathrm{~m})$ water temperature $\left({ }^{\circ} \mathrm{C}\right)$ and salinity (psu) for each area. Nos. in parentheses: number of stations in each area (total of 163 stations); letters beside each bar: areas with significantly different thermohaline values

depth (m). Correlations between PCA-ENV and fishing temperature, salinity and depth were $-0.93,0.86$ and 0.79 , respectively, so that positive PCA-ENV values indicate cold, saline, deep habitats and negative values warm, fresher, shallow habitats.

Almost half the variation in NMDS Axis 1 was accounted for by physical parameters represented in PCA-ENV $\left(r^{2}=0.41, p<0.0001\right.$, Fig. 4). Pollock were associated with relatively cold, saline and deep water. Conversely, sand lance and herring were more abundant in relatively warm, less saline and shallow water (Fig. 4). These 2 species co-occurred at 47 sites that were typically nearshore, with an average station depth of $40 \mathrm{~m}$. Fishing depth at these sites was shallow $(\bar{x}=19 \mathrm{~m})$ and had warm average temperature $(\bar{x}=$ $\left.10.7^{\circ} \mathrm{C}\right)$ and low average salinity $(\bar{x}=30.7 \mathrm{psu})$. In contrast, sites where pollock were present had an average fishing depth of $40 \mathrm{~m}$, average temperature of $9^{\circ} \mathrm{C}$, and average salinity of 31.7 psu. Axis 1 captures the geographic variability in forage fish communities in the upwelling 'cold core' area of lower Cook Inlet from the Barrens and mouth of Cook Inlet to Kachemak Bay (Kruskal-Wallis test statistic $H=19.52$, df $=2$, $\mathrm{p}<$ 0.0001, Fig. 5).

The PCA-ENV variable accounted for some variation in NMDS Axis $2\left(r^{2}=0.12, p<0.0001\right.$, Fig. 4). The relationship between Axis 2 and PCA-ENV indicates 
Table 1. Percent species composition at Chisik, Kachemak, the Barrens, and all areas combined. Data are for all years combined (1996 to 1999). Frequency of occurrence is listed for all areas and years combined, and represents percent of stations where species was present. Species are listed in order of catch-per-unit-effort (no. fishes $\mathrm{km}^{-1}$ ). Shannon-Wiener diversity index and species richness are also shown. $-:<0.1$

\begin{tabular}{|c|c|c|c|c|c|c|}
\hline \multirow[t]{2}{*}{ Species } & \multirow[t]{2}{*}{ Common name } & \multicolumn{4}{|c|}{ \% composition } & \multirow[t]{2}{*}{$\%$ frequency } \\
\hline & & Chisik & Kachemak & Barrens & All areas & \\
\hline Ammodytes hexapterus & Pacific sand lance & 60.7 & 83.5 & 66.4 & 71.0 & 61 \\
\hline Clupea pallasi & Pacific herring & 0.8 & 3.6 & 24.2 & 17.7 & 33 \\
\hline Theragra chalcogramma & Walleye pollock & 1.9 & 10.7 & 8.3 & 8.8 & 50 \\
\hline Mallotus villosus & Capelin & 23.5 & 0.5 & 1.1 & 1.7 & 27 \\
\hline Gadus macrocephalus & Pacific cod & 0.9 & 0.9 & - & 0.3 & 33 \\
\hline Lumpenus spp. & Lumpenus & 1.5 & 0.4 & - & 0.2 & 10 \\
\hline Oncorhynchus gorbuscha & Pink salmon & 1.7 & 0.3 & 0 & 0.1 & 10 \\
\hline Spirinchus thaleichthys & Longfin smelt & 4.5 & 0 & 0 & 0.1 & 6 \\
\hline Trichodon trichodon & Pacific sandfish & 1.6 & - & 0 & 0.1 & 11 \\
\hline Oncorhynchus tshawytscha & Chinook salmon & 1.3 & - & 0 & - & 16 \\
\hline Oncorhynchus nerka & Sockeye salmon & 0.4 & - & 0 & - & 6 \\
\hline Atherestes stomias & Arrowtooth flounder & 0.2 & - & - & - & 3 \\
\hline Ophiodon elongatus & Lingcod & 0.3 & - & - & - & 2 \\
\hline Zaprora silenus & Prowfish & - & - & - & - & 9 \\
\hline Liparis spp. & Snailfishes & 0.1 & - & - & - & 4 \\
\hline Lycodes brevipes & Shortfin eelpout & 0.1 & 0 & 0 & - & 1 \\
\hline Psychrolutes paradoxus & Tadpole sculpin & 0 & - & - & - & 2 \\
\hline Thaleichthys pacificus & Eulachon & 0.1 & 0 & 0 & - & 2 \\
\hline Hexagrammos stelleri & White-spotted greenling & 0.1 & 0 & 0 & - & 2 \\
\hline Lampetra tridentata & Pacific lamprey & 0.1 & 0 & 0 & - & 4 \\
\hline Blepsias bilobus & Crested sculpin & - & - & - & - & 3 \\
\hline Gymnocanthus galeatus & Armorhead sculpin & - & 0 & 0 & - & 1 \\
\hline Hippoglossus stenolepis & Pacific halibut & - & - & - & - & 2 \\
\hline Pallasina barbata & Tubenose poacher & - & - & 0 & - & 2 \\
\hline Gasterosteus aculeatus & Threespine stickleback & - & 0 & 0 & - & 1 \\
\hline Sarritor sp. & Poacher & 0 & - & - & - & 2 \\
\hline Podothecus acipenserinus & Sturgeon poacher & - & 0 & 0 & - & 1 \\
\hline Aspidophoroides bartoni & Aleutian alligatorfish & - & 0 & 0 & - & 1 \\
\hline Oncorhynchus kisutch & Coho salmon & 0 & - & 0 & - & 1 \\
\hline Hemitripterus villosus & Shaggy sea raven & 0 & - & 0 & - & 1 \\
\hline Anoplagonus inermis & Smooth alligatorfish & - & - & 0 & - & 1 \\
\hline Myoxocephalus polyacanthocephalus & Great sculpin & 0 & - & - & - & 1 \\
\hline Sebastes spp. & Rockfishes & 0 & - & 0 & - & 1 \\
\hline Icelinus borealis & Northern sculpin & - & 0 & 0 & - & 1 \\
\hline Hippoglossoides elassodon & Flathead sole & 0 & - & - & - & 1 \\
\hline Dasycottus setiger & Spinyhead sculpin & - & 0 & 0 & - & 1 \\
\hline Triglops pingeli & Ribbed sculpin & - & 0 & 0 & - & 1 \\
\hline Microstomus pacificus & Dover sole & - & 0 & 0 & - & 1 \\
\hline Gymnocanthus sp. & Sculpin & - & 0 & 0 & - & 1 \\
\hline Shannon-Wiener diversity index & & 1.30 & 0.63 & 0.87 & & \\
\hline Species richness & & 32 & 25 & 16 & & \\
\hline No. of tows & & 41 & 65 & 57 & & \\
\hline
\end{tabular}

that the community represented by chinook salmon, pink salmon, Lumpenus spp., Pacific sandfish, Pacific cod and longfin smelt tends to be associated with warmer, less saline and shallower mid-water habitats than those occupied by sand lance (relatively colder, more saline, deeper). Geographically, Axis 2 was significantly most negative at Chisik and most positive at the Barrens $(H=22.17$, df $=2, \mathrm{p}<0.0001$, Fig. 5), indicating that sand lance were caught mostly in southern Cook Inlet, while most other species (salmonids, Lumpenus spp., Pacific sandfish, longfin smelt) with nega- tive correlations were caught mainly in northern lower Cook Inlet around Chisik (Table 1). This result corresponds with high values of species diversity and richness at Chisik. Axis 2 essentially captures the spatial variability in forage fish communities from the north (Chisik) to the south (Barrens) of lower Cook Inlet, possibly in relation to the salinity and temperature gradients among areas (Figs. 2 \& 3).

Sand lance were the most abundant species in the study area (Table 1) and were present at 52 sites that did not have herring. Stations with sand lance and no 
Table 2. Spearman rank-correlations between 3 axes of species composition and catch-per-unit-effort of individual species. A species was associated with an axis if it had a rankcorrelation of \pm 0.35 or greater; -: rank-correlations less than \pm 0.35 . Species listed in order of decreasing abundance. Mean energy density ( $\mathrm{kJ} \mathrm{g}^{-1}$ wet mass, from Anthony et al. 2000) is listed for each species where available. Lipid content is the primary determinant of energy density, and is scaled as high $(\mathrm{H})$, medium $(\mathrm{M})$, or low $(\mathrm{L})$. na: not available

\begin{tabular}{|lccccc|}
\hline $\begin{array}{l}\text { Common } \\
\text { name }\end{array}$ & $\begin{array}{c}\text { Axis } \\
1\end{array}$ & $\begin{array}{c}\text { Axis } \\
2\end{array}$ & $\begin{array}{c}\text { Axis } \\
3\end{array}$ & $\begin{array}{c}\text { Energy } \\
\text { density } \\
\left(\mathrm{kJ} \mathrm{g}^{-1}\right)\end{array}$ & $\begin{array}{c}\text { Lipid } \\
\text { content }\end{array}$ \\
\hline Pacific sand lance & 0.72 & 0.61 & - & 5.40 & $\mathrm{H}$ \\
Pacific herring & 0.59 & - & - & 3.69 & $\mathrm{~L}$ \\
Walleye pollock & -0.86 & - & - & 3.47 & $\mathrm{~L}$ \\
Capelin & - & - & 0.72 & 5.04 & $\mathrm{H}$ \\
Pacific cod & - & -0.40 & -0.69 & 3.60 & $\mathrm{~L}$ \\
Lumpenus spp. & - & -0.45 & - & 4.73 & $\mathrm{M}$ \\
Pink salmon & - & -0.48 & - & 3.41 & $\mathrm{~L}$ \\
Longfin smelt & - & -0.35 & - & na & \\
Pacific sandfish & - & -0.41 & - & 3.55 & $\mathrm{~L}$ \\
Chinook salmon & - & -0.53 & - & na & \\
Sockeye salmon & - & - & - & 4.35 & $\mathrm{M}$ \\
Prowfish & - & - & - & 2.84 & $\mathrm{~L}$ \\
\hline
\end{tabular}

herring tended to be offshore and had an average bottom depth of $63 \mathrm{~m}$. Fishing depth at these sites was deeper $(\bar{x}=31 \mathrm{~m})$, with a cooler average temperature $\left(\bar{x}=9.6^{\circ} \mathrm{C}\right)$, and a higher average salinity $(\bar{x}=31.1 \mathrm{psu})$ than those habitats with both herring and sand lance present.

The PCA-ENV variable did not account for variation in NMDS Axis $3\left(\mathrm{r}^{2}=0.01, \mathrm{p}=0.3289\right)$. Axis 3 indicates that capelin and Pacific cod are negatively spatially associated (Table 2), but this negative association was not related to physical parameters such as temperature or salinity. Variation in Axis 3 was, however, related to area $(H=27.95$, df $=2, \mathrm{p}<0.0001$, Fig. 6). Juvenile Pacific cod were more abundant in Kachemak, while capelin were more abundant in Chisik and the Barrens.

\section{NMDS variation in relation to year}

All NMDS axes varied significantly among years. Axis 1 was more negative in 1996 than in any other year, and 1996 and 1997 were more negative than $1999(H=38.38$, df $=3, \mathrm{p}<0.0001$, Fig. 6), thereby indicating that from 1996 to 1999 the relative abundance of pollock (lipid-poor) decreased significantly while that of sand lance (lipid-rich) and herring increased significantly (Table 2). Axis 2 was more negative in 1997 than in any other year $(H=13.06$, $\mathrm{df}=3, \mathrm{p}=0.0045)$, but it was difficult to interpret interannual variation in Axis 2 without a clear increasing or decreasing trend among years. Axis 3 was most positive in $1999(H=18.51$, df $=3, \mathrm{p}=$ 0.0003, Fig. 6), corresponding to a positive rank of capelin (lipid-rich) and a negative rank of Pacific cod (lipid-poor, Table 2). Interannual variation in Axis 3 indicated that from 1996 to 1999 the relative abun-

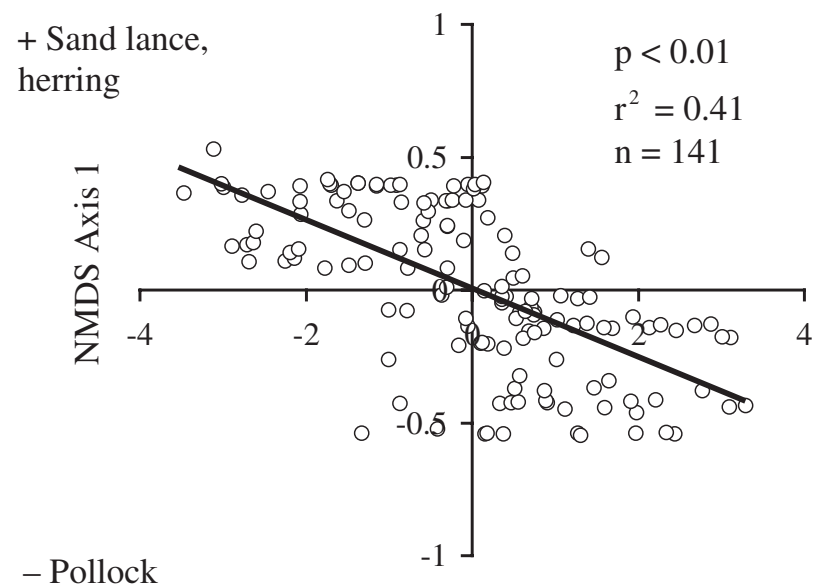

- Pollock

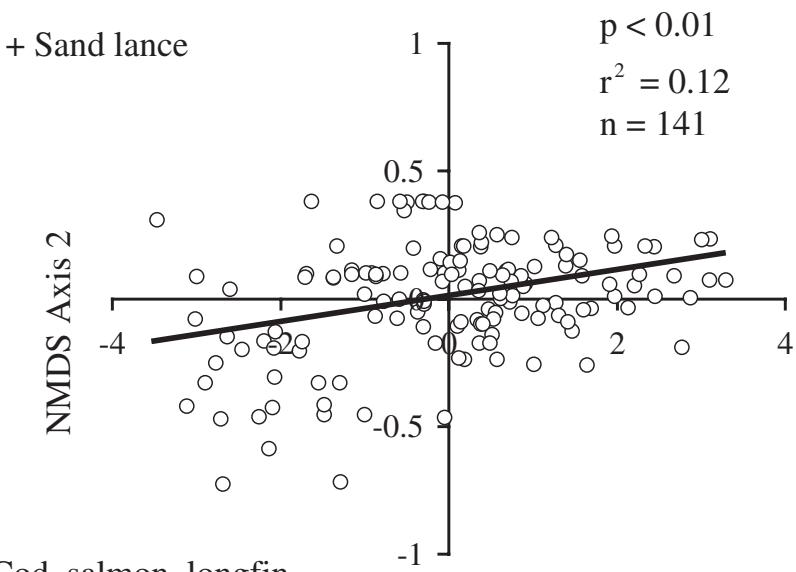

- Cod, salmon, longfin

smelt, sandfish, Lumpenus

Warm,

Shallow, $\mathrm{PCA}-\mathrm{ENV} \longrightarrow \begin{aligned} & \text { Cold, } \\ & \text { Deep, }\end{aligned}$

Less saline

More saline

Fig. 4. Scatter-plots of non-metric multidimensional scaling (NMDS) Axes 1 and 2 in relation to environmental variable (principal component analysis, PCA-ENV). Each $y$-axis is labeled with fish species that represent a positive or negative index of species composition (see Table 2); along $x$-axis, positive PCA-ENV value indicates cold, deep, more saline water, negative value warm, shallow, less saline water. Linear regression lines were plotted and corresponding values for $\mathrm{p}, \mathrm{r}^{2}$ and $\mathrm{n}$ are given. PCA-ENV variable did not account for significant variation in Axis 3 and is not shown 


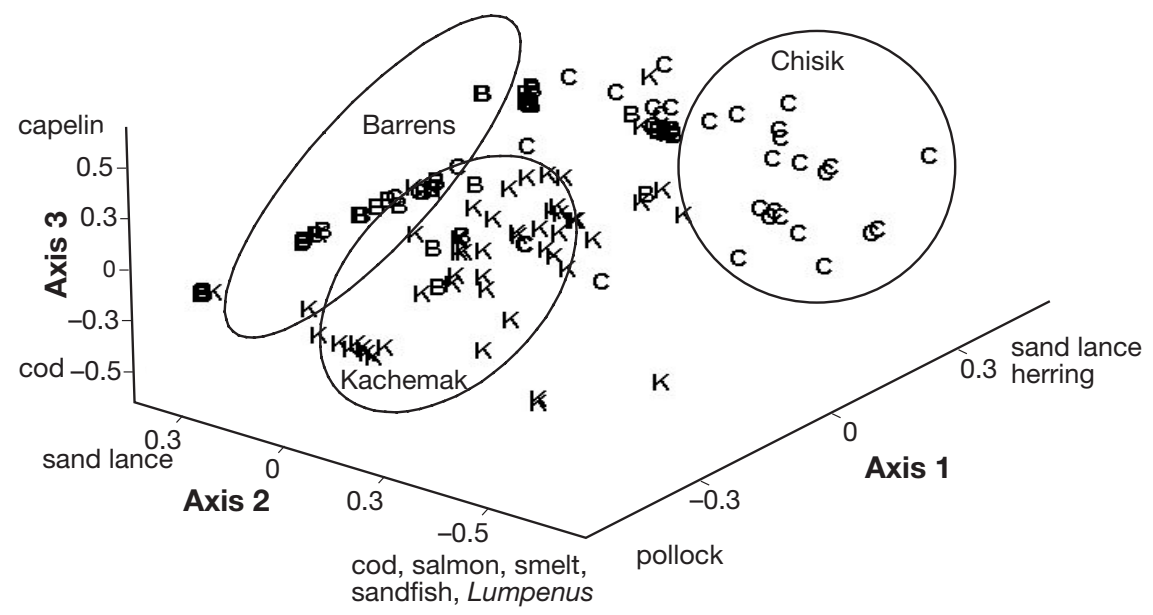

Fig. 5. 3D scatter-plot showing spatial variability in the 3 NMDS axes by area. All axes varied significantly among areas: Axis 1 essentially captures spatial variability in forage fish communities in coldcore area of lower Cook Inlet (Kachemak, Barrens), Axis 2 the spatial variability in forage fish communities from the north (Chisik) to the south (Barrens) of lower Cook Inlet, and Axis 3 contrasts negative geographic association of capelin (Chisik, Barrens) and cod (Kachemak). Note that Axis 2 decreases from left to right dance of capelin in the mid-water fish community increased significantly, while the relative abundance of Pacific cod decreased. rous predators such as seabirds and marine mammals, and corresponding changes in their biology and population size (Piatt \& Anderson 1996, Francis et al. 1998).

\section{DISCUSSION}

The forage fish community in lower Cook Inlet is primarily structured along temperature and salinity gradients. Wide ranges of mid-water habitats were sampled, ranging from highly stratified and estuarine to upwelled, exposed areas. Among all the habitats sampled, fishing temperature, salinity and depth explained $41 \%$ of the spatial variability for $97 \%$ of the fish captured in trawls (Fig. 4), as represented by the dominant species of sand lance, herring and pollock. Because forage fishes vary markedly in nutritive value, this spatial variability results in structuring of local areas into lipid-poor (Chisik) and lipidrich (Kachemak, the Barrens) communities. Furthermore, piscivore populations in lower Cook Inlet have correspondingly declined where the prey base is lipid-poor (Chisik) and increased in the lipid-rich regions of Kachemak and the Barrens (Piatt \& Anderson 1996, Piatt 2002). Our findings may extend to much larger spatial scales. Recent evidence indicates that water temperature plays a major role in structuring fish communities in the north Pacific, as seen in the spatial organization of nearshore demersal fish assemblages (Mueter \& Norcross 1999) and a multidecadal reorganization of forage fishes and groundfishes in the Gulf of Alaska (Anderson \& Piatt 1999, Mueter \& Norcross 2000). Again, this structuring has resulted in longterm changes in diet composition of piscivo-

\section{Species richness and diversity}

The range of water temperatures and salinities in the stratified water column at Chisik yielded the highest species richness and diversity. Collections at Chisik consisted of some high-lipid fishes (especially osmerids) and mostly lower-lipid species (salmonids, Pacific sandfish and Lumpenus spp.). The warm, low-salinity surface waters at Chisik provided a different habitat from that at

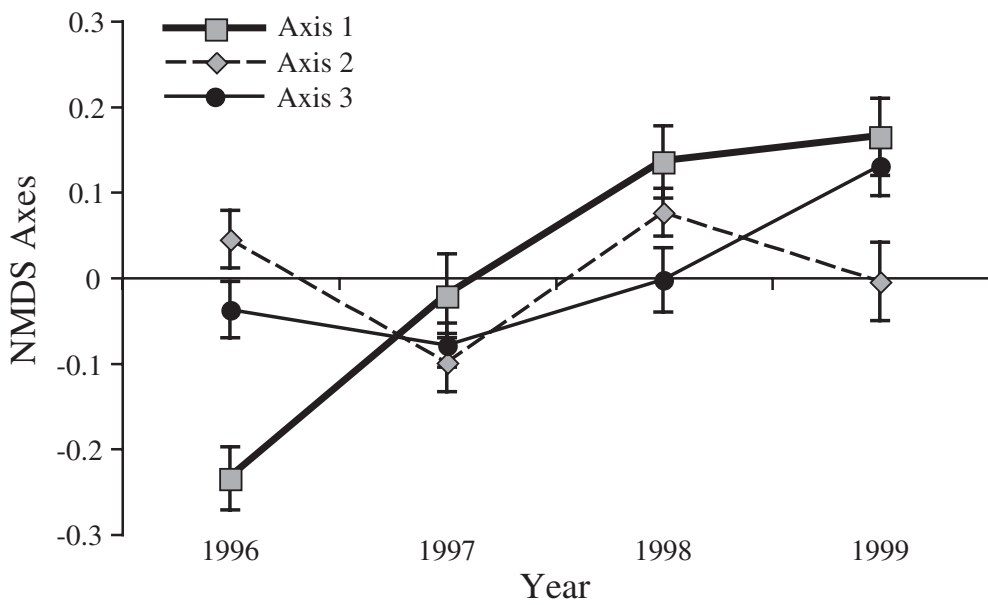

Fig. 6. NMDS axis means ( \pm SE) by year (1996 to 1999). All axes varied significantly among years. Interannual variation in Axis 1 indicates that from 1996 to 1999 relative abundance of pollock (lipid-poor) decreased significantly while that of sand lance (lipid-rich) and herring increased significantly (Table 2), interannual variation in Axis 3 indicates that from 1996 to 1999 relative abundance of high-lipid capelin in mid-water fish community increased significantly, while relative abundance of low-lipid Pacific cod decreased 
Kachemak and the Barrens, and promoted a more diverse fish assemblage. Juvenile salmonids and osmerids need lower-salinity water in order to acclimatize to marine conditions (St. John et al. 1992). Additionally, for juvenile salmonids, salinity gradients act as an orientation mechanism during outward migration from a freshwater habitat to an oceanic habitat (McInerney 1964), and in upper Cook Inlet the abundance of juvenile salmonids is inversely correlated with surface salinity (Moulton 1997). Kachemak Bay is a mixture of estuarine waters, with some input from oceanic, upwelled waters (Muench et al. 1978, Abookire et al. 2000); consequently, thermohaline values in Kachemak Bay lay between those at Chisik and the Barrens. While species diversity was lowest in Kachemak Bay, species richness there was intermediate between that in the Barrens and in Chisik. In contrast, in the Barren Islands, where upwelling occurs regularly (Muench et al. 1978) and waters are the most oceanic, species richness was lowest, and mid-water fish schools were dominated by 1 to 2 species, mostly pollock in offshore waters and sand lance in nearshore waters.

\section{Spatial variation in the mid-water fish community}

Spatial patterns in the mid-water fish community of Cook Inlet were similar to those found nearshore. Sand lance dominated the mid-water fish community and were ubiquitous on the shelf throughout lower Cook Inlet. Similarly, sand lance dominated the nearshore fish communities in Kachemak Bay and on the west side of Kodiak Island in the 1970s (Blackburn \& Anderson 1997) as well as in lower Cook Inlet in the late 1990s (Robards et al. 1999b). Large single-species schools of sand lance were captured in waters that were colder and more saline than those with both herring and sand lance present. While sand lance concentrate in surface layers of stratified estuaries (McGurk \& Warburton 1992, Abookire et al. 2000), they are also commonly found in bays, inshore waters, and over continental shelves (McGurk \& Warburton 1992 and references therein, Robards et al. 2002). Given that sand lance can exploit a wide range of thermohaline habitats, it is not surprising that they dominate the forage fish community in lower Cook Inlet.

Mid-water schools of herring were captured on the shelf in association with dense aggregations of sand lance. This species association was also observed in nearshore waters of lower Cook Inlet in the late 1970s (Blackburn \& Anderson 1997). Juvenile herring concentrate nearshore and at the surface (Hourston 1958, Sturdevant et al. 2001), in stratified estuaries (Abookire et al. 2000), and especially in areas with freshwater input where they benefit from increased concentrations of zooplankton (St. John et al. 1992). In lower Cook Inlet, herring are restricted to warmer, less saline habitats, which sand lance may also occupy but to which they are not limited.

The 2 species of gadids (both lipid-poor) distributed themselves in different areas and differently with respect to oceanographic parameters. Pollock were abundant in cold, more saline waters that were usually associated with deeper water. However, pollock were occasionally captured at shallow $(<10 \mathrm{~m})$ depths that had low temperatures and high salinity, located in the 'cold core' upwelling region of lower Cook Inlet. Similarly, Wilson et al. (1996) captured Age 0 walleye pollock (44 to $102 \mathrm{~mm}$ ) at depths from near-surface to near-bottom $(200 \mathrm{~m})$ and suggested that their vertical positioning over a range of depths may be influenced by a suite of environmental variables including temperature, light, diel period and thermocline depth. The warm, less saline waters at Chisik probably exclude pollock, which tended to concentrate around the Barrens and in Kachemak. In contrast, Pacific cod were distributed in nearshore habitats that were warmer and less saline than those used by pollock. Concentrations of Pacific cod in Kachemak may reflect their occasional use of Kachemak Bay as a nursery area once they settle to a demersal habitat (Abookire et al. 2001).

\section{Temporal variation in the mid-water fish community}

From 1996 to 1999 sand lance and herring increased in the forage fish community in lower Cook Inlet. This may have been related in part to the 1997/1998 ENSO event that elevated sea-surface temperatures by 1 to $2{ }^{\circ} \mathrm{C}$ above average during the summer of 1998 , and warmed the entire water column by $>1^{\circ} \mathrm{C}$ during the fall and winter of 1997 to 1998 in the Gulf of Alaska (Piatt et al. 1999) and in lower Cook Inlet (Drew \& Piatt 2002). Because sand lance spawn in October and larvae hatch by late December (Robards et al. 1999c), the warmer waters in winter 1997/1998 may have enhanced sand lance growth and survival. Robards et al. (2002) found that juvenile sand lance grew most slowly at Chisik, moderately fast in Kachemak, and fastest at the Barrens. They concluded that while these growth differences corresponded to spatially distinct thermohaline habitats, sand lance growth and recruitment was more likely to be affected by changes in their planktonic food than by temperature alone. Likewise, in the North Sea, poor recruitment of Ammodytes marinus occurred in warm years due to the negative effects of water temperature on abundance of their copepod prey (Arnott \& Ruxton 2002).

Because capelin abundance declined sharply in the North Pacific during the regime shift of the late 1970s, 
they are regarded as an indicator species for changing environmental or ecological conditions (Piatt \& Anderson 1996, Anderson \& Piatt 1999, Anderson 2000). The relative abundance of capelin in the mid-water fish community of lower Cook Inlet increased in 1999, a year with cooler surface temperatures (NOAA NOS website, 23 May 2003: www.co-ops.nos.noaa.gov/). Capelin may have been responding to an overall cooling trend of water temperatures in the North Pacific (Hare \& Mantua 2000, Chavez et al. 2003). In cold years, the capelin spawning season is delayed (Methven \& Piatt 1991, Carscadden et al. 1997) and better synchronized with the zooplankton bloom (Mackas et al. 1998), thereby providing a mechanism for their increased growth and survival during cool years.

While restricted to a moderately sized geographic area, the interannual variation in the mid-water fish community structure in lower Cook Inlet is interesting in the context of the decadal regime shift that occurred in the Gulf of Alaska (Anderson \& Piatt 1999, Anderson 2000, Mueter \& Norcross 2000). Following the 1976/1977 regime shift, warm water temperatures in the Gulf of Alaska were advantageous for gadid populations (Anderson \& Piatt 1999, Anderson 2000, Mueter \& Norcross 2000). Warmer water temperatures have also been advantageous to walleye pollock survival in the Bering Sea, where cold years yield lower pollock recruitment (Walsh \& McRoy 1986). The decrease in relative abundance of juvenile gadids (both pollock and Pacific cod) combined with the increase in capelin from 1996 to 1999 provide biological support for the suggestion that the Pacific Ocean will shift back to a cool regime (Chavez et al. 2003). In 1999, sea-surface temperatures in the Gulf of Alaska near Kodiak, Alaska, were the coldest on record since 1974 (NOAA data). While lower Cook Inlet comprises only a small geographical area of the Gulf of Alaska, from 1971 to 2000 similar trends in surface-water temperature have been observed in both Kachemak Bay (Drew \& Piatt 2002) and the Gulf of Alaska (Royer 1989, Anderson \& Piatt 1999, Hare \& Mantua 2000).

\section{CONCLUSION}

The forage fish community in lower Cook Inlet was structured along gradients of temperature and salinity. Different oceanographic conditions structured forage fishes into lipid-rich and lipid-poor communities. The large temperature and salinity differential between estuarine (Chisik) and oceanic (the Barrens) habitats in lower Cook Inlet allows mid-water fishes to distribute themselves amongst a wide range of thermohaline habitats in the water column. On the other hand, dependence on specific thermohaline habitats may constrain populations and provide a mechanism for the effect of climatic forcing on marine fish assemblages (McGowan et al. 1998, Attrill \& Power 2002, Chavez et al. 2003). Interannual trends in relative abundance of gadids (lipidpoor) and capelin (lipid-rich) in lower Cook Inlet support suggestions that there has been a large-scale shift to a cool regime in the Pacific Ocean during the late 1990s (Chavez et al. 2003). Because forage fishes vary in lipid content and caloric value, a shift in ocean climate could have direct consequences on the foraging success and survival of piscivores through a reorganization of forage fish community-structure.

Acknowledgements. We thank Captains P. Desjardins and M. Hottman along with the crew of the RV 'Pandalus': B. Harris, R. Gustin, M. Parrish, and E. Hofseth. We are grateful for the hardworking scientific crew that included D. Black, G. Drew, C. Lascink, B. Seymour, S. Speckman, and especially J. Figurski. Fig. 1 was drafted by S. Speckman and finalized by C. Armistead. F. Mueter generously assisted with statistical methods, interpretation and NMDS programming. We thank M. Litzow and S. Speckman for their helpful comments on earlier drafts of the manuscript, and P. J. Anderson, F. Mueter, $\mathrm{M}$. Wilson, and 4 anonymous reviewers for thoroughly critiquing the manuscript. This project was funded by the 'Exxon Valdez' Oil Spill Trustee Council (Restoration Project 00163M), and the US Geological Survey.

\section{LITERATURE CITED}

Abookire AA, Piatt JF, Robards MD (2000) Nearshore fish distributions in an Alaskan estuary in relation to stratification, temperature and salinity. Estuar Coast Shelf Sci 51:45-59

Abookire AA, Piatt JF, Norcross BL (2001) Juvenile groundfish habitat in Kachemak Bay, Alaska, during late summer. Alaska Fish Res Bull 8:45-56

Anderson PJ (2000) Pandalid shrimp as indicators of ecosystem regime shift. J Northwest Atl Fish Sci 27:1-10

Anderson PJ, Piatt JF (1999) Community reorganization in the Gulf of Alaska following ocean climate regime shift. Mar Ecol Prog Ser 189:117-123

Anderson PJ, Blackburn JE, Johnson BA (1997) Declines of forage species in the Gulf of Alaska, 1972-1995, as an indicator of regime shift. In: Mecklenburg CW (ed) Forage fishes in marine ecosystems. Alaska Sea Grant College, University of Alaska, Fairbanks, p 531-544

Anthony JA, Roby DD, Turco KR (2000) Lipid content and energy density of forage fishes from the northern Gulf of Alaska. J Exp Mar Biol Ecol 248:53-78

Arnott SA, Ruxton GD (2002) Sandeel recruitment in the North Sea: demographic, climatic and trophic effects. Mar Ecol Prog Ser 238:199-210

Attrill MJ, Power M (2002) Climatic influence on a marine fish assemblage. Nature 417:275-278

Bailey KM, Piatt JF, Royer TC, Macklin SA and 9 others (1995) ENSO events in the Northern Gulf of Alaska, and effects on selected marine fisheries. Calif Coop Oceanic Fish Investig Rep 36:78-96

Bechtol WR (1997) Changes in forage fish populations in Kachemak Bay, Alaska, 1976-1995. In: Mecklenburg CW (ed) Forage fishes in marine ecosystems. Alaska Sea Grant College, University of Alaska, Fairbanks, p 441-456

Blackburn JE, Anderson PJ (1997) Pacific sand lance growth, 
seasonal availability, movements, catch variability, and food in the Kodiak-Cook Inlet area of Alaska. In: Mecklenburg CW (ed) Forage fishes in marine ecosystems. Alaska Sea Grant College, University of Alaska, Fairbanks, p 409-426

Blackburn JE, Anderson K, Hamilton CI, Starr SJ (1980) Pelagic and demersal fish assessment in the lower Cook Inlet estuary system. NOAA Final Rep Outer Cont Shelf Environ Assess Program Biol Stud 12:259-602

Carscadden J, Nakashima BS, Frank KT (1997) Effects of fish length and temperature on the timing of peak spawning in capelin (Mallotus villosus). Can J Fish Aquat Sci 54: 781-787

Chavez FP, Ryan J, Lluch-Cota SE, Niquen M (2003) From anchovies to sardines and back: multidecadal change in the Pacific Ocean. Science 299:217-221

Drew GS, Piatt JF (2002) Oceanography of lower Cook Inlet. In: Piatt JF (ed) Response of seabirds to fluctuations in forage fish density. Final Report to Exxon Valdez Oil Spill Trustee Council (Restoration Project 00163M) and Minerals Management Service (Alaska OCS Region). Alaska Science Center, US Geological Survey, Anchorage, Alaska, p 17-25

Field JG, Clarke KR, Warwick RM (1982) A practical strategy for analyzing multispecies distribution patterns. Mar Ecol Prog Ser 8:37-52

Francis RC, Hare SR, Hollowed AB, Wooster WS (1998) Effects of interdecadal climate variability on the oceanic ecosystems of the NE Pacific. Fish Oceanogr 7:1-21

Hare SR, Mantua NJ (2000) Empirical evidence for North Pacific regime shifts in 1977 and 1989. Prog Oceanogr 47:103-145

Hourston AS (1958) Population studies on juvenile Pacific herring in Barkley Sound, British Columbia. J Fish Res Board Can 15:909-960

Kitaysky AS, Golubova EG (2000) Climate change causes contrasting trends in reproductive performance of planktivorous and piscivorous alcids. J Anim Ecol 69:248-262

Krebs CJ (1989) Ecological methodology. Harper \& Row, New York

Kruskal JB (1964) Multidimensional scaling by optimizing goodness of fit to a nonmetric hypothesis. Psychometrika 29:1-27

Mackas DL, Goldblatt R, Lewis AG (1998) Interdecadal variation in developmental timing of Neocalanus plumchrus populations at Ocean Station $\mathrm{P}$ in the subarctic North Pacific. Can J Fish Aquat Sci 55:1878-1893

McGowan JA, Cayan DR, Dorman LM (1998) Climate-ocean variability and ecosystem response in the Northeast Pacific. Science 281:210-217

McGurk MD, Warburton HD (1992) Pacific sand lance of the Port Moller estuary, southeastern Bering Sea: an estuarine-dependent early life history. Fish Oceanogr 1:306-320

McInerney JE (1964) Salinity preference: an orientation mechanism in salmon migration. J Fish Res Board Can 21:995-1018

Merrick RS, Loughlin TR, Calkins DG (1987) Decline in abundance of the northern sea lion, Eumetopias jubatus, in Alaska, 1956-86. Fish Bull US 85:351-365

Methven DA, Piatt JF (1991) Seasonal abundance and vertical distribution of capelin (Mallotus villosus) in relation to water temperature at a coastal site off eastern Newfoundland. ICES J Mar Sci 48:187-193

Moulton LL (1997) Early marine residence, growth, and feeding by juvenile salmon in northern Cook Inlet, Alaska. Alaska Fish Res Bull 4:154-177

Muench RD, Mofjeld HO, Charnell RL (1978) Oceanographic conditions in lower Cook Inlet: spring and summer 1973. J Geophys Res 83:5090-5098

Mueter FJ, Norcross BL (1999) Linking community structure of small demersal fishes around Kodiak Island, Alaska, to environmental variables. Mar Ecol Prog Ser 190:37-51

Mueter FJ, Norcross BL (2000) Changes in species composition of demersal fish community in nearshore waters of Kodiak Island, Alaska. Can J Fish Aquat Sci 57:1169-1180

Mysak LA (1986) El Niño, interannual variability and fisheries in the northeast Pacific Ocean. Can J Fish Aquat Sci 43:464-497

Payne SA, Johnson BA, Otto RS (1999) Proximate composition of some north-eastern Pacific forage fish species. Fish Oceanogr 8:159-177

Piatt JF (ed) (2002) Response of seabirds to fluctuations in forage fish density. Final Report to Exxon Valdez Oil Spill Trustee Council (Restoration Project 00163M) and Minerals Management Service (Alaska OCS Region). Alaska Science Center, US Geological Survey, Anchorage, AK

Piatt JF, Anderson PJ (1996) Response of common murres to the Exxon Valdez oil spill and long-term changes in the Gulf of Alaska marine ecosystem. Am Fish Soc Symp 18:720-737

Piatt JF, Drew G, Van Pelt T, Abookire A, Nielsen A, Shultz M, Kitaysky A (1999) Biological effects of the 1997/1998 ENSO in Cook Inlet, Alaska. Pac Mar Sci Org (PICES) Sci Rep 10:93-99

Robards MD, Anthony JA, Rose GA, Piatt JF (1999a) Changes in proximate composition and somatic energy content for Pacific sand lance (Ammodytes hexapterus) from Kachemak Bay, Alaska relative to maturity and season. J Exp Mar Biol Ecol 242:245-258

Robards MD, Piatt JF, Kettle AB, Abookire AA (1999b) Temporal and geographic variation in fish communities of lower Cook Inlet, Alaska. Fish Bull US 97:962-977

Robards MD, Piatt JF, Rose GA (1999c) Maturation, fecundity, and intertidal spawning of Pacific sand lance (Ammodytes hexapterus) in the northern Gulf of Alaska. J Fish Biol 54:1050-1068

Robards MD, Rose GA, Piatt JF (2002) Growth and abundance of Pacific sand lance, Ammodytes hexapterus, under differing oceanographic regimes. Environ Biol Fishes 64: $429-441$

Royer TC (1975) Seasonal variations of waters in the northern Gulf of Alaska. Deep-Sea Res 22:403-416

Royer TC (1989) Upper ocean temperature variability in the northeastern Pacific Ocean: is it an indicator of global warming? J Geophys Res 98:4639-4644

Speckman SG, Piatt JF (2002) Hydroacoustic forage fish biomass and distribution in Cook Inlet. In: Piatt JF (ed) Response of seabirds to fluctuations in forage fish density. Final Report to Exxon Valdez Oil Spill Trustee Council (Restoration Project 00163M) and Minerals Management Service (Alaska OCS Region). Alaska Science Center, US Geological Survey, Anchorage, AK, p 55-63

Springer AM, Speckman SG (1997) A forage fish is what? Summary of the Symposium. In: Baxter B, Mecklenberg CW (eds) Forage fishes in marine ecosystems. Proceedings of the International Symposium on the Role of Forage Fishes in Marine Ecosystems. Alaska Sea Grant College Program Report No. 97-01. University of Alaska Fairbanks, AK, p 773-805

Statistical Sciences (1995) S-PLUS Version 3.3 for Windows. StatSci, a division of MathSoft, Seattle

Stenseth NC, Mysterud A, Ottersen G, Hurrell JW, Chan K, Lima M (2002) Ecological effects of climate fluctuations. Science 297:1292-1296 
St. John MA, Macdonald JS, Harrison PJ, Beamish RJ, Choromanski E (1992) The Fraser River plume: some preliminary observations on the distribution of juvenile salmon, herring, and their prey. Fish Oceanogr 1:153-162

Sturdevant MV, Brase ALJ, Hulbert LB (2001) Feeding habits, prey fields, and potential competition of young-of-theyear walleye pollock (Theragra chalcogramma) and Pacific herring (Clupea pallasi) in Prince William Sound, Alaska, 1994-1995. Fish Bull US 99:482-501

Editorial responsibility: Otto Kinne (Editor-in-Chief), Oldendorf/Luhe, Germany
Van Pelt TI, Piatt JF, Lance BK, Roby DD (1997) Proximate composition and energy density of some North Pacific forage fishes. Comp Biochem Physiol 118:1393-1398

Walsh JJ, McRoy CP (1986) Ecosystem analysis in the southeastern Bering Sea. Cont Shelf Res 5:259-288

Wilson MT, Brodeur RD, Hinckley S (1996) Distribution and abundance of age-0 walleye pollock, Theragra chalcogramma, in the western Gulf of Alaska during September 1990. NOAA Tech Rep NMFS 126:11-24

Submitted: December 17, 2003; Accepted: August 31, 2004 Proofs received from author(s): January 31, 2005 